\title{
Adoption of Omni-channel in Millennial Consumers through Omni-Interaction
}

\author{
$1^{\text {st }}$ Djohan Gunawan ${ }^{1}, 2^{\text {nd }}$ Tirta Nugraha Mursitama ${ }^{2}, 3^{\text {rd }}$ Amalia E. Maulana $^{3}, 4^{\text {th }}$ Mohammad \\ $\mathrm{Hamsal}^{4}$

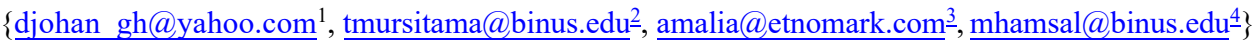

\author{
Student of BINUS Business School - Doctor of Research in Management Palmerah, Jakarta, Indonesia ${ }^{1}$ \\ Vice Rector Research and Technology Transfer, Bina Nusantara University, Palmerah, Jakarta, \\ Indonesia ${ }^{2}$ \\ Lecturer of Magister Management Bina Nusantara University Palmerah, Jakarta, Indonesia ${ }^{3}$ \\ Lecturer of Doctor of Research in Management, Bina Nusantara University Palmerah, Jakarta, Indonesia ${ }^{4}$
}

\begin{abstract}
Because of technology, the retail environment has shifted from being mostly offline to being primarily online to now being both online and offline, or omni-channel. Using an omnichannel approach, retailers can provide customers with a shopping experience that is seamless across all channels. By allowing real-time engagement, retailers may enable customers to interact online or offline across all channels at any time and from any location. A generation of young people, the millennials constitute $50 \%$ of the world's population in 2017 , and their buying power makes them an important target for the consumer goods and services sectors. Millennials, on the other hand, are characterized by their status as users and consumers of technology. The purpose of this article is to investigate the variables that influence online or offline contact throughout the buying experience in the adoption of omni-channel shopping, as influenced by the behavior of millennials.

This study was evaluated using a sample of data gathered from a survey of the millennial generation, which was conducted in the United Kingdom. Millennial purchasing behavior and omni-channel adoption are both regulated by shopping experience, according to the findings, which suggest that the main drivers of omni-channel interaction have a substantial effect on shopping experience, which is moderated by shopping experience. Because the findings provide a description of how omni-channel retailing is implemented, it is necessary to understand customers and their experiences in order to develop a complete process of omni-channel retailing that is simple for both consumers and retailers.
\end{abstract}

Keywords: omni-channel, consumer, millennial, retail, purchase behaviour, adoption, experience, interaction

\section{Introduction}

According to Kotler, Hermawan and Iwan (2016), the digital era is known as the era of Marketing 4.0 is a marketing strategy that mixes online and offline contact, and it is becoming more popular. The digital and physical worlds are merging together with no discernible differences between them, whether from the viewpoint of the consumer or the business (Rigby, 2011). The growth of the Internet and cellphones has transformed the retail industry, enabling customers to browse for goods and buy comfortably from any location, at any time of day (Egol, Rajagopalan and Sayer, 2012). Retail developed from a single channel to a cross-channel to a multi-channel and finally an omni-channel model through time (Nicol, 2013; Brynjolfsson, Hu and Rahman, 2013; Angel, 2014; Melero, Sese and Verhoef, 2016). 
According to Carvalho and Campomar (2014), the new retail model that has emerged from the multi-channel concept is referred to as omni-channel, and it achieves maximum efficiency by combining physical and online distribution channels. Marketing using offline marketing (Laudon, Kenneth, and Traver, 2015) makes it simple for both customers and sellers to do business (Lazaris and Vrechopoulos, 2014; McCormick et al, 2014; Rigby, 2011; Rigby, 2014). Hansen and Sia (2015) argue that businesses must concentrate on improvements in technological infrastructure and organizational processes in order to effectively alter the economy via the implementation of an omni-channel strategy.

The term "omni-channel" refers to a situation in which consumers perceive all of a retailer's channels to be one entity, and the shopping experience is seamless regardless of which channels the customer utilizes (Herhausen et al, 2015). The most distinguishing feature of the omnichannel strategy is that it is focused on the consumer and the purchasing experience, with the goal of providing the shopper with a comprehensive shopping experience (Gupta, Lehmann and Stuart, 2004). An omni-channel retailing strategy is a collection of actions that involves selling a product or service via all available channels at the same time, with complete customer contact prompted by the retailer and complete integration controlled by the retailer (Beck and Rygl, 2015).

According to Aubrey and Judge (2012), technological advancements have altered customer attitudes and habits. A generation of young people born between 1980 and 2000 (Caraher, 2015), millennials are increasingly empowered consumers with a wide range of options and full authority as the world shifts from traditional to digital. They are defined by their use and adaptation of technology in their daily lives as well as their shared values, life experiences, and common purchasing behaviors. Pew Research (2012) estimates that they will constitute $50 \%$ of the world's population by 2017. (Kotler, Hermawan and Iwan, 2016; Flor et al, 2017). Due to the fact that they represent half of global consumption, the millennial generation has emerged as an interesting group to research since their habits vary from those of previous generations, and it is for this reason that researching them has gained significance and relevance (Smith, 2011).

Adoption of omni-channel has gained significance, as shown by many studies that have emphasized the importance of adopting new technology in terms of customer acceptability and willingness to utilize that new technology (Meuter, Ostrom, Roundtree and Bitner, 2000; Venkatesh, Thong and Xu, 2012; Lai and Zainal, 2015; Lai, 2016). Consumer acceptance and usage of technology were the focus of Emma, Ana, and Yolanda (2016)'s research on the adoption of the newest retail model, omni-channel, which they conducted in 2016. Aiolfi and Edoardo (2017) provide an overview of the possible advantages and results arising from the implementation of an omni-channel strategy, including increased sales and profitability, the development of omni-channel loyalty, and the creation of a long-term connection with consumers. Purchase intentions are used to make purchases in research from Emma and Ana (2016), while behavioral intentions are used in research from Venkatesh, Morris, Davis, and Davis (2003), and Raffaele (2014) uses information adoption to make purchase decisions in research from Venkatesh, Morris, Davis and Davis (2003).

\subsection{The Omni-Interaction Concept}

Customer service must be excellent and consistent across all channels in order for an omnichannel strategy to be successful (Gorsch, 2002; Gupta, Lehmann and Stuart, 2004). The focus on interactions between channels and brands, how these interactions operate, and the integration of consumer, brand, and retail channels is increased with the introduction of omni-channel 
marketing (Neslin et al, 2014). During the search, buy, and post-purchase phases of the process, interactions are utilized seamlessly and alternately (Verhoef, Kannan and Inman, 2015).

A purchase process may be completed on a variety of channels that are connected with omnichannel customers (Angel, 2014), integrating online and offline marketing (Laudon, Kenneth, et al., 2015), and providing consumers with a greater number of options when making purchases (Fernie, J. Fernie, S. and Christopher, 2015). The term "omni-channel retailing" has become popular in recent years, referring to a process that makes it easy for consumers and retailers to interact (Lazaris and Vrechopoulos, 2014; McCormick et al., 2014; Rigby, 2011; Rigby, 2014; Carvalho and Campomar, 2014), and that understands customers and their experiences (Lazaris and Vrechopoulos, 2014). (Puccinelli et al, 2009).

\section{H1: Omni-interaction positively influence Omni-experience in retail Omni-channel}

\subsection{Omni-Experience}

The aim of adopting omni-channel retailing is to provide consumers with a seamless shopping experience by integrating the advantages of both online and physical shopping channels (Rigby, 2011; Frazer et al, 2014). Customers may meditate and think on their purchases in a peaceful environment while shopping online, allowing them to do so in the comfort of their own homes (Zhang et al. 2010). The conventional offline channels are used for professional guidance; if the customer enjoys touch-and-feel shopping while also wanting to save time on delivery, the traditional offline channels are used (Kollmann, Andreas and Ina, 2012).

The difficulty comes in the integration of channels; the aim of creating an omni-channel strategy is to provide a positive customer experience (Frazer et al, 2014). Regardless of the channel through which they interact, customers expect a consistent, uniform, and integrated service or experience; they are willing to move seamlessly between channels depending on their preferences, their current situation, the time of day, or the product category; and they expect seamless integration between channels (Cook, 2014; Piotrowicz, and Cuthbertson, 2014). Consumers try to accomplish some objective by buying and utilizing a specific product or service, which may be used to better understand retailing and consumer experiences (Ratneshwar, David and Cythia, 2000). A successful implementation of an omni-channel strategy that includes comprehensive integration of all channels has the potential to significantly improve the shopping experience for the consumer, as shown by customer feedback (Herhausen et al, 2015). Understanding and putting out the necessary work to develop an omni-channel experience is no longer a choice, but rather a must (Winter, 2012).

The customer experience in retailing is defined specifically by Verhoef et al. (2009) as a multi-dimensional concept that is holistic in character and encompasses the consumer's cognitive, affective, emotional, social, and physical reactions to a store. When it comes to consumer behavior, Peter and Olson (2010) define it as a combination of thoughts and emotions experienced as well as actions performed throughout the purchasing and consuming process. According to additional research by Oliver (1997), Oliver (1999), Da Silva and Syed (2006), Carvalho and Campomar (2014), Garaus, Wagner, and Kummer (2015), Agnieszka (2017), and Juan (2017), the perceived benefits of using online services will positively influence consumer attitudes and intentions, which are based on cognitive, affective, and conative factors that are the foundation of the theory of consumer attitudes (Fishbein, and Ajzen, 1975).

H2: Adoption of Omni-channel in Retail Omni-channel is favorably influenced by the Omniexperience.

Consumer Purchase Behavior among Millennials (1.3) 
The Millennial generation has played a significant role in the growth of e-Commerce during the last several years (Abdul, Jianhua and Kalsoom, 2017). It is expected that they would account for half of the world's population by 2017. (Kotler, Hermawan and Iwan, 2016; Smith, 2011; Flor et al, 2017). These young individuals, who were born between 1980 and 2000 (according to Caraher, 2015), have been characterized as open-minded socially conscious innovators who are also active, ambitious, dependable, driven, and bright (Guven, 2015). Having grown up in a technologically developing environment, this generation has taken a more active role in integrating technologies into their everyday lives for marketing reasons, using their mobile devices as well as conventional Internet methods to interact with merchants or brand representatives (Moore, 2012).

According to Cook (2014), millennials are omni-channel customers who are active (mobile) and highly connected, and who make extensive use of technology in their everyday lives. According to Aubrey and Judge (2012), technological advancements have altered customer attitudes and habits. Marketing research is something they actively engage in. They do this by downloading apps that are helpful for them to remain connected to shops or brands (Moore, 2012).

H3: Purchase by a Millennial In the retail omni-channel environment, consumer behavior has a beneficial influence on the connection between Omni-interaction and Omni-experience.

Based on the foregoing information and hypotheses, the purpose of this paper is to investigate the factors that influence online and/or offline or omni-interaction during the shopping for omni-experience in the adoption of omni-channel, as moderated by millennial purchase behavior, during the shopping for omni-experience. In this study, the novelty is that omni-interaction may be used as a factor in the adoption of many channels.

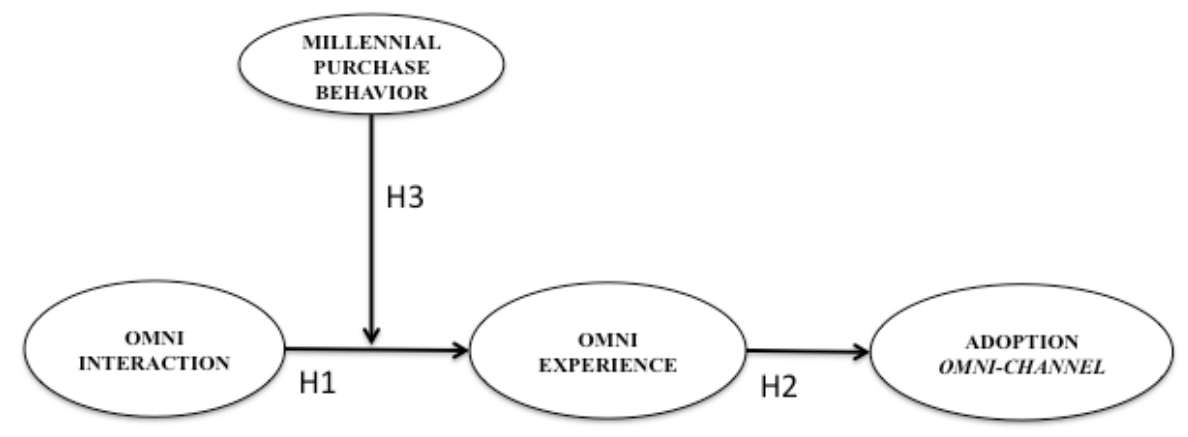

Fig. 1. Research model

According to the findings of this study, the following research model (Figure 1) is developed, which focuses on the omni-interaction as an exogenous variable, the omni-experience as an intervening variable, adoption omni-channel as an endogenous variable, and millennial purchase behaviors as a moderating factor. This section covers omni-interaction, omni-experience, millennial purchasing behavior, and omni-channel adoption, and it offers hypotheses relating to these topics.

Methods of Investigation

The questionnaire was divided into two sections. The first section contained statements about retail omni-channel that represented the four variables investigated in the research on millennial retail omni-channel consumers (Table 1). Respondents were instructed to rate their 
agreement with each item on a four-point Likert scale ranging from 1 (strongly disagree) to 4 (strongly agree); respondents were instructed to rate their agreement with each item on a fourpoint Likert scale ranging from 1 (strongly disagree) to 4 (strongly agree) (strongly agree). A non-probability with accidental sampling technique was used to gather data from millennials in Indonesia via questionnaires that were distributed across the country. In all, 261 respondents stated that they had made a recent purchase during the previous 12 months prior to the data collection (September 2019).

Table 1. Variable, Constructs and items, included in the questions

\begin{tabular}{|c|c|c|c|}
\hline Variable & Construct & Item & Measurement \\
\hline \multirow[t]{3}{*}{ Omni-Interaction } & Information & OI-1 & $\begin{array}{l}\text { I feel a consistent of product and sales information on } \\
\text { all available channels. }\end{array}$ \\
\hline & Process & OI-2 & $\begin{array}{l}\text { I feel a consistent of purchase process on all available } \\
\text { channels }\end{array}$ \\
\hline & Data & OI-3 & $\begin{array}{l}\text { I feel a consistent of integrated consumer data on all } \\
\text { available channel }\end{array}$ \\
\hline \multirow[t]{3}{*}{ Omni-Experience } & Cognitive & OE-1 & $\begin{array}{l}\text { I feel pleasured when easily get the variety of information } \\
\text { on all available channels }\end{array}$ \\
\hline & Affective & OE-2 & $\begin{array}{l}\text { I feel satisfied when received good service of purchase on } \\
\text { all available channels }\end{array}$ \\
\hline & Conative & OE-3 & $\begin{array}{l}\text { I feel confortable when I have many choices to purchase } \\
\text { on all available channels }\end{array}$ \\
\hline \multirow{2}{*}{$\begin{array}{l}\text { Millennial } \\
\text { Purchase } \\
\text { Behaviour }\end{array}$} & Mobile & MP-1 & $\begin{array}{l}\text { I like to be active or mobile and highly connected use } \\
\text { technology in daily lives }\end{array}$ \\
\hline & Innovative & MP-2 & I like to get involved in offering of new products \\
\hline \multirow[t]{3}{*}{$\begin{array}{l}\text { Adoption Omni- } \\
\text { Channel }\end{array}$} & Purchase & AO-1 & $\begin{array}{l}\text { I am willing to purchase through retail on all available } \\
\text { channel because of easiness process }\end{array}$ \\
\hline & Behaviour & $\mathrm{AO}-2$ & $\begin{array}{l}\text { I am willing to purchase through retail on all available } \\
\text { channel because of technology }\end{array}$ \\
\hline & Information & $\mathrm{AO}-3$ & $\begin{array}{l}\text { I am willing to purchase through retail on all available } \\
\text { channel because of integrity of information }\end{array}$ \\
\hline
\end{tabular}

The second section of the questionnaire was used to collect socio-demographic information, such as gender, age, job position, and educational attainment, from the participants and their families. The characteristics of respondents were almost same for males (51 percent) and females (49 percent), as well as for the quartile of millennial age (28 percent , 24 percent , 23 percent and 26 percent ). The majority of respondents ( 71 percent) are bachelors and work as employees (72 percent ). The majority of online purchases are made using a smartphone (97 percent) and one online transaction is made each month (56 percent ). 


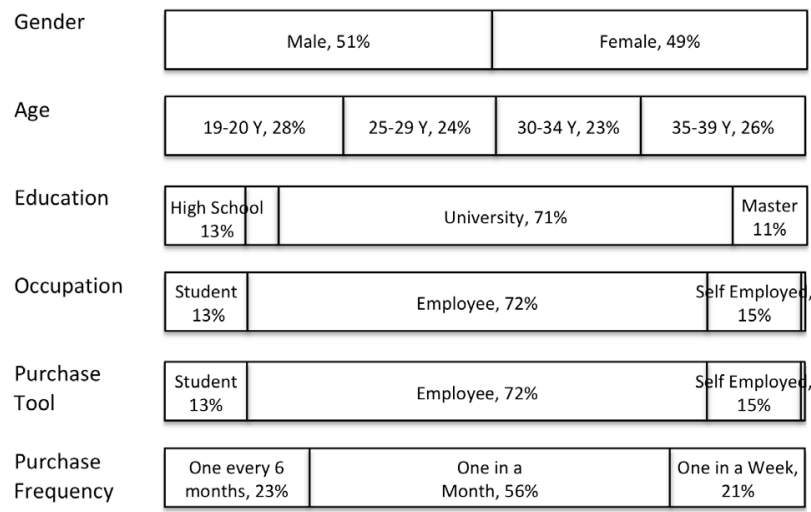

Figure 2. Respondent Characteristic

\section{Result and Discussions}

When it came to testing the assumptions, the variance-based partial least squares (PLS) route modeling method was used (Ringle, Wende and Will, 2005). PLS route models are classified into two categories: inner models and outer models (Figure 3). As a result, SmartPLS 3.0 was utilized to evaluate the hypotheses in this investigation. A bootstrap method was also used to evaluate the model's stability, which was also successful.

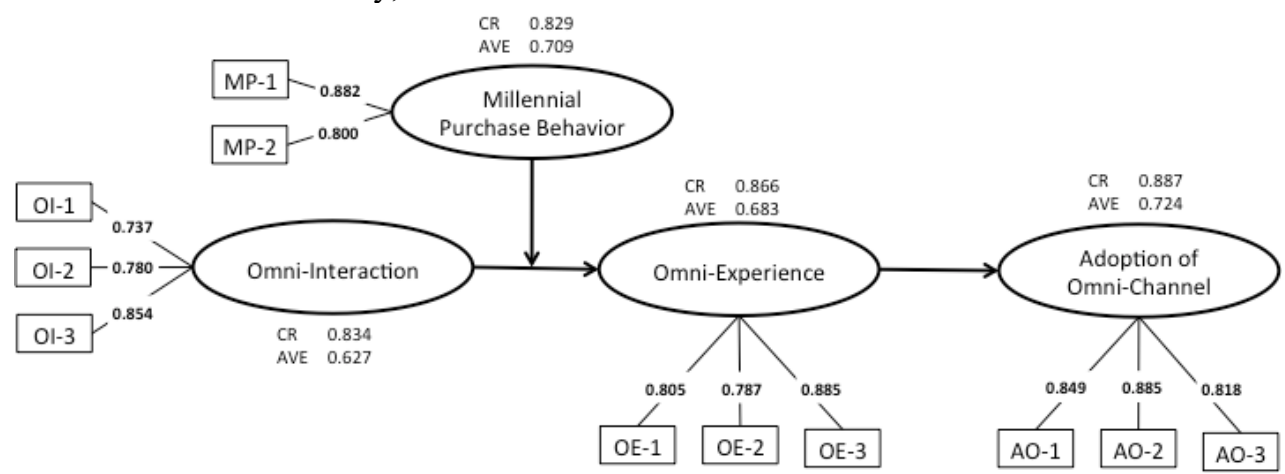

Fig. 3. Smart PLS Result

In accordance with the findings (Table 2), all items have a statistically significant, standardized loading factor higher than 0.50 . The average variance extracted (AVE) for all variables had a loading factor greater than 0.50 , indicating that they were valid for measuring their constructs, and the composite reliability (CR) for all variables was greater than 0.7 (Nunnally, 1978), indicating that all variables met the reliability requirements. 
Table 2. Results of Validity and Reliability

\begin{tabular}{|c|c|c|c|c|c|c|}
\hline \multicolumn{2}{|l|}{ Items } & \multirow{2}{*}{$\begin{array}{l}\text { Loading } \\
\text { Factor }\end{array}$} & \multirow{2}{*}{$\begin{array}{c}\text { Composite } \\
\text { Reliability }\end{array}$} & \multirow{2}{*}{$\begin{array}{c}\text { Average Variance } \\
\text { Extracted (AVE) } \\
\mathbf{0 . 6 2 7}\end{array}$} & \multirow{2}{*}{$\begin{array}{c}\text { Relationshi } \\
\text { p }\end{array}$} & \multirow{2}{*}{$\begin{array}{c}\text { Measurement } \\
\text { Valid and Reliable }\end{array}$} \\
\hline Omni-Interaction & & & & & & \\
\hline - Information & OI-1 & 0.737 & & & Significant & \\
\hline - Process & $\mathrm{OI}-2$ & 0.780 & & & Significant & \\
\hline - Data & OI-3 & 0.854 & & & Significant & \\
\hline Omni-Experience & & & 0.866 & 0.683 & & Valid and Reliable \\
\hline - Cognitive & OE-1 & 0.805 & & & Significant & \\
\hline - Affective & OE-2 & 0.787 & & & Significant & \\
\hline - Conative & OE-3 & 0.885 & & & Significant & \\
\hline \multicolumn{3}{|c|}{ Millennial Purchase Behaviour } & 0.829 & 0.709 & & Valid and Reliable \\
\hline - Mobile & MP-1 & 0.882 & & & Significant & \\
\hline - Innovative & MP-2 & 0.800 & & & Significant & \\
\hline \multicolumn{3}{|c|}{ Adoption Omni-Channel } & 0.887 & 0.724 & & Valid and Reliable \\
\hline - Purchase & $\mathrm{AO}-1$ & 0.849 & & & Significant & \\
\hline - Behaviour & $\mathrm{AO}-2$ & 0.855 & & & Significant & \\
\hline - Information & $\mathrm{AO}-3$ & 0.818 & & & Significant & \\
\hline
\end{tabular}

Once the measurement model met the elements of validity and reliability, the model was executed using bootstrapping to measure the research model (Figure 4).

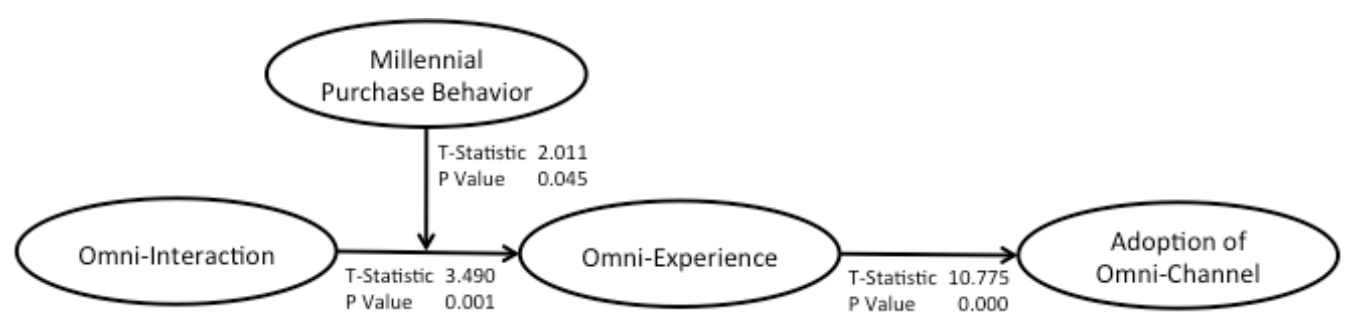

Figure 4. Smart PLS Bootstrapping Result

In the first hypothesis (H1), we looked at how omni-interaction and omni-experience were related to one another. In Table 3, it is revealed that the measurements included a T-statistics value of 3.490 (more than 0.196 ) and a P-value of 0.001 (less than 0.05 ), suggesting that omniinteraction has an important impact on omni-experience. Consumer attitudes and intentions toward using online services will be positively influenced by perceived benefits, according to previous research by Oliver (1997), Oliver (1999), Da Silva and Syed (2006), Garaus, Wagner, and Kummer (2015), which found that perceived benefits of using online services will positively influence consumer attitudes and intentions toward using online services.

Table 3. Results of Measurement Model Variables 


\begin{tabular}{lcccc}
\hline \multicolumn{1}{c}{ Hypothesis } & $\begin{array}{c}\text { Original } \\
\text { Sample }\end{array}$ & $\begin{array}{c}\text { T } \\
\text { Statistics }\end{array}$ & $\begin{array}{c}\text { P } \\
\text { Values }\end{array}$ & Result \\
\hline 1. Omni-Interaction $\square$ Omni-Experience & 0.196 & 3.490 & 0.001 & Significant \\
& & & & H1: Accepted \\
2. Omni-Experience $\square$ Adoption Omni-channel & 0.572 & 10.775 & 0.000 & Strongly \\
& & & & Significant \\
3. Moderating $\square$ Omni-Experience & & & & H2: Accepted \\
& 0.084 & 2.011 & 0.045 & Significant \\
& & & & H3: Accepted \\
\hline
\end{tabular}

According to H2's T-statistics value of 10.775 (more than 0.196 ) and P-value of 0.000 (less than 0.05 ), omni-experience has a very significant impact on the adoption of omni-channel. The third hypothesis: H3 addressed the connection between omni-experience and the adoption of omni-channel. These findings are consistent with previous research conducted by Emma, Ana, and Yolanda (2016), which provided theoretical understanding of the anticipated use of omnishopper technology in connection with the initial adoption of omni-channel by focusing on the acceptance and use of technology used by customers during the information and purchase stages of the purchasing process.

The third hypothesis, $\mathrm{H} 3$, addressed the relationship between millennial purchase behaviors as a moderator variable for omni-interaction and omni-experience, which had a T-statistics value of $2.011(>0.196)$ and a P-value of $0.045(0.05)$, which showed that moderating means that moderating strengthens omni-experience. The fourth hypothesis, H4, addressed the relationship between millennial purchase behaviors as a moderator variable for omni-interaction and omniThese results are consistent with prior research, which explains that millennials are more inclined toward making purchases more often and more impulsively (Lissitsa and Ofrit , 2016). During the search, buy, and post-purchase phases of the process, interactions are utilized seamlessly and alternately (Verhoef, Kannan and Inman, 2015).

The following assumptions were confirmed by the findings: H1: Omni-interaction has a major impact on the Omni-experience in retail Omni-channel, and H2: Omni-experience has a significant impact on the Omni-experience in retail Omni-channel Retail Omni-channel adoption is higher than H3: Millennial purchasing behavior. In the retail omni-channel environment, positive reinforcement of behavior improves the connection between Omniinteraction and Omni-experience.

\section{Conclusion}

As a result of the evolution of the retail industry, a new phenomena known as omni-channel retailing has emerged (Herhausen et al, 2015). In general, the omni-channel strategy is focused on the consumer and the customer's purchasing experience, with the goal of providing the shopper with a more complete shopping experience in general (Gupta, Lehmann and Stuart, 2004). It is possible to describe this phenomena as the customer management approach that is implemented throughout the customer's life cycle. When it comes to becoming an omni-channel customer, the millennial is active (mobile), highly connected, and actively uses technology in their everyday life (Cook, 2014). 
It is the goal of this study to explore the relationship between omni-interaction and omniexperience in depth. Influence the adoption of omni-channel marketing, with millennial buying behavior acting as a moderator. Following the study, the hypotheses were confirmed by statistically significant evidence, which further reinforces the link between millennial buying behavior, omni-interaction, omni-experience, and adoption of omni-channel technologies. Understands customers and their experiences (Puccinelli et al., 2009), and develops a complete method of omni-channel retailing that is simple for both consumers and retailers to use and understand (Lazaris and Vrechopoulos, 2014; McCormick et al, 2014; Rigby, 2011; Rigby, 2014; Carvalho and Campomar, 2014).

It is important to note that the respondents in this study were drawn from a sample of millennials who were active consumers of online merchants in Indonesia. It's possible that the omni-channel will have various impacts in different parts of the world. It would be interesting to repeat this research in a different generation or in an other nation in order to compare the outcomes.

\section{References}

[1] Abdul Waheed; Jianhua Yang; and Kalsoom Rafique (2017), Understanding the effect of e-Marketing (eM) on online consumer buying behavior. International Conference on Management Engineering.

[2] Agnieszka Kurczewska; Paula Kyrö; Krista Lagus; Oskar Kohonen; and Tiina LindhKnuutila, (2017), The interplay between cognitive, conative, and affective constructs along the entrepreneurial learning process, Education + Training (C) Emerald Publishing Limited.

[3] Aiolfi Simone and Edoardo Sabbadin (2017), The new paradigm of the omnichannel retailing: key drivers, new challenges and potential outcomes resulting from the adoption of an omnichannel approach, International Journal of Business and Management.

[4] Angel, T.O.S. (2014), A study of omni-channel retailing: the impact of integration quality on omni-channel satisfaction and omni-channel loyalty in apparel retail business. The Hongkong Polytechnic University.

[5] Aubrey, C. and Judge, D. (2012), Re-imagine retail: why store innovation is key to a brand's growth in the new normal, digitally-connected and transparent world, Journal of Brand Strategy.

[6] Beck, N., and Rygl, D. (2015), Categorization of multiple channel retailing in multichannel and omni-channel retailing for retailers and retailing, Journal Retail.

[7] Brynjolfsson, E.; Hu, Y. J.; and Rahman, M. S. (2013), Competing in the age of omnichannel retailing. MIT Sloan Management.

[8] Caraher, Lee (2015), Millennials \& management. Biblieomotion, Inc.

[9] Carvalho, J.L.G. and Campomar, M.C. (2014), Multichannel at retail and omni channel: challenges for marketing and logistic. Business and Management Review.

[10] Cook, G. (2014), Customer experience in the omni-channel world and the challenges and opportunities this presents, Journal Dir. Data Digital.

[11] Da Silva, R.V. and Syed, S.F. (2006), Cognitive, affective attributes and conative, behavioral responses in retail corporate branding. Journal of Product and Brand Management.

[12] Egol, M. Rajagopalan, A. and Sayer, B. (2012), E-commerce and consumer goods: a strategy for omni-channel success. Pricewaterhouse Coopers / PwC.

[13] Emma Juaneda-Ayensa; Ana Mosquera and Yolanda Sierra Murillo (2016), Omnichannel customer behavior: key drivers of technology acceptance and use and their 
effects on purchase intention. Frontiers in Psychology.

[14] Fernie, John; Fernie, Suzanne and Christopher Moore (2015), Principles of retailing, Routledge, London

[15] Fishbein, M. and Ajzen, I. (1975), Belief, attitude, intention, and behavior: an introduction to theory and research. Addison-Wesley.

[16] Flor Madrigal Moreno; Jaime Gil Lafuente; Fernando Ávila Carreón; and Salvador Madrigal Moreno (2017), The characterization of the millennials and their buying behavior. International Journal of Marketing Studies.

[17] Frazer, M. and Stiehler, E. (2014), Omni-channel retailing: the merging of the daring and luring environment. Global Conference on Business and Finance Proceedings.

[18] Garaus, M.; Wagner, U. and Kummer, C. (2015), Cognitive fit, retail shopper confusion, and shopping value: empirical investigation. Journal of Business Research.

[19] Görsch, D. (2002), Multi-channel integration and its implications for retail web Sites, in ECIS 2002 Proceedings, June 6-8, Gdańsk, Poland.

[20] Gupta, S.; Lehmann, D. R. and Stuart, J. A. (2004), Valuing customers. Journal Marketing.

[21] Guven Ordun (2015), Millennial (Gen y) consumer behavior, their shopping preferences and perceptual maps associated with brand loyalty, Canadian Academy of Oriental and Occidental Culture, Canadian Social Science.

[22] Hansen, R., and Sia, S. K. (2015), Hummel's digital transformation toward omnichannel retailing: Key lessons learned. MIS Quarterly Executive, .

[23] Herhausen, Dennis, Jochen Binder, Marcus Schoegel and Andreas Herrman (2015), Integrating bricks with clicks: retailer-level and channel-level outcomes of online-offline channel integration, Journal of Retailing.

[24] Juan Carlos Bustamante, Natalia Rubio, (2017) Measuring customer experience in physical retail environments, Journal of Service Management.

[25] Kollmann, Tobias; Andreas Kuckertz; and Ina Kayser, (2012), Cannibalization or synergy? consumers' channel selection in online-offline multichannel systems, Journal of Retailing and Consumer Services

[26] Kotler, P.; Hermawan Kartajaya; and Iwan Setiawan (2016), Marketing 4.0: Moving from traditional to digital. Wiley.

[27] Lai, P. C. (2016), Design and security impact on consumers' intention to use single platform e-payment, Interdisciplinary Information Sciences.

[28] Lai, P. C. and Zainal, A. A. (2015), Consumers' intention to use a single platform epayment system: a study among malaysian internet and mobile banking users. Journal of Internet Banking and Commerce.

[29] Laudon, Kenneth C. and Traver, Carol G. (2015). E-Commerce 2015: Business, technology, society (11 edition). Pearson Education, Londan

[30] Lazaris, C. and Vrechopoulos, A. (2014), From multichannel to "omni-channel" retailing: review of the literature and calls for research. 2nd International Conference on Contemporary Marketing Issues (ICCMI) Athens.

[31] Lissitsa Sabina and Ofrit Kol (2016), Generation X vs. Generation Y - A decade of daring shopping. Journal of Retailing and Consumer Services.

[32] McCormick, H.; Cartwright, J.; Perry, P.; Barnes, L.; Lynch, S.; and Ball, G. (2014), Fashion retailing - past, present and future. Textile Progress.

[33] Melero, I.; Sese, F.; and Verhoef, P. C. (2016), Recasting the customer experience in today's omni-channel environment. Univ. Business Review.

[34] Meuter, M. L.; Ostrom, A. L.; Roundtree, R. I.; and Bitner, M. J. (2000), Self-service 
technologies: understanding customer satisfaction with technology-based service encounters. Journal of Marketing.

[35] Moore, M. (2012), Interactive media usage among millennial consumers. Journal of Consumer Marketing.

[36] Neslin, S. A.; Jerath, K.; Bodapati, A.; Bradlow, E. T.; Deighton, J. and Gensler, S. (2014), The interrelationships between brand and channel choice. Marketing Letter, A Journal of Research in Marketing.

[37] Nicol, Dirk (2013), Mobile strategy: How your company can win by embracing mobile technologies. Pearson Education, Boston.

[38] Nunnally, J. (Eds. 2). (1978), Psychometric theory. New York: McGraw-Hill.

[39] Oliver, R.L. (1997), "Satisfaction: A behavioral perspective on the consumer, 2nd edition." New York: Routledge.

[40] Oliver, R.L. (1999), Whence consumer loyalty? Journal Marketing.

[41] Peter, J, P. and Olson, J.C. (2010), Consumer behavior and marketing strategy 9th edition. McGraw Hill, New York.

[42] Piotrowicz, W. and Cuthbertson, R. (2014), Introduction to the special issue information technology in retail: Toward omnichannel retailing, International Journal Electronic Commercial.

[43] Puccinelli, N. M.; Goodstein, R. C.; Grewal, D.; Price, R.; Raghubir, P. and Stewart, D. (2009), Customer experience management in retailing: understanding the buying process. Journal of Retailing.

[44] Raffaele Filieri (2014), What makes online reviews helpful? a diagnosticity-adoption framework to explain informational and normative influences in e-WOM, Journal of Business Research.

[45] Ratneshwar, S., David Mick and Cythia Huffman (2000), The why of consumption: Contemporary perspectives on consumer motives, goals and desires, New York: Routledge.

[46] Rigby, Darrell K (2011), The future of shopping. Harvard Business Review.

[47] Rigby, Darrell K (2014), Digital-physical mashups. Harvard Business Review.

[48] Ringle, C. M., Wende, S. and Will, A. (2005), SmartPLS 2.0 (beta). Hamburg: www.smartpls.de.

[49] Smith, K. T. (2011), Digital marketing strategies that millennials find appealing, motivating, or just annoying. Journal of Strategic Marketing.

[50] Venkatesh, V.; Morris, M.; Davis, G.; and Davis, F. (2003), User acceptance of information technology: Toward a unified view. MIS.

[51] Venkatesh, V.; Thong, J. Y. L.; and Xu, X. (2012), Consumer Acceptance and use of information technology: Extending the unified theory of acceptance and use of technology. MIS.

[52] Verhoef, P. C.; Kannan, P. K. and Inman, J. J. (2015), From multi-channel retailing to omni-channel retailing: Introduction to the special issue on multi-channel retailing. Journal Retail.

[53] Verhoef, Peter C., Katherine N. Lemon, A. Parasuraman, Anne Roggeveen, Leonard A. Schlesinger and Michael Tsiros (2009), Customer Experience: determinants, dynamics and management strategies, Journal of Retailing.

[54] Winter, R. (2012). The omnichannel shopper Display \& Design Ideas Review.

[55] Zhang, J., Farris, P.W., Irvin, J.W., Kushwaha, T., Steenburgh, T.J., Weitz, B.A., (2010), Crafting integrated multichannel retailing strategies. Journal Interact. 